\title{
Study on the Sports Lifestyle of Rural Adolescents in Yunnan Border Areas
}

\author{
Kaiwen Li \\ Wenshan College \\ Wenshan, China 663000
}

\author{
Peng Nie \\ Yunnan Police Officer Academy \\ Kunming, China 650223
}

\author{
Wu Liu \\ Yunnan institute of technology of profession of mechanical \\ and electrical \\ Kunming, China 650203
}

\begin{abstract}
This study applies questionnaires, randomly stratifies 552 adolescents of both genders from 26 towns in Yunnan border areas, investigates the sports lifestyle of rural adolescents in Yunnan border areas, and also analyzes the influencing factors. And the following conclusions are obtained. Students' participation degree in physical exercise is relatively higher in school, but the purpose of participation is not clear, sports items they participate are single, physical examinationoriented education is obvious, exercise time is short, sports consumption capacity is weak, and fewer students can persist in exercising for a long term. Students' participation degree in physical exercise is relatively lower in their spare time, the main sports item is game, and their time is mainly filled with homework and chores. And individual subjective factor, family economic factor and social-oriented factor are the main influencing factors for the sports lifestyle of rural adolescents.
\end{abstract}

Keywords-border areas; adolescents; sports lifestyle

\section{INTRODUCTION}

Lifestyle is first mentioned by sociologist Max Weber, and he thinks it mainly refers to a series of habits, attitudes and development of all aspects generated from the influences of all kinds of external environment in a long time, such as personal preferences, hobbies, cognition and so on. In 1994, the World Health Organization (WHO) proposed seven central tasks including "making sports to become the cornerstone of healthy lifestyle"1. Many scholars in China have studied sports lifestyle, and this paper agrees on the concept proposed by Li Wenchuan, that is, sport lifestyle is a stable form and behavior characteristic that under the guidance of certain values, certain individuals or groups treat sports as the need and content of life on the basis of objective conditions, and regularly and consciously participate in sports activities2. Individual development in adolescence is the fastest, and good sports lifestyle during this period is an important factor affecting physical health, mental health, growth and development of adolescents. And due to the influence of many natural factors, economic factors and other development factors, the sports lifestyle and physical

M Scientific Research Fund Program of Yunnan Provincial Department of Education, Project No: 2103 Y263 exercise behavior of rural adolescents in Yunnan border areas need to be improved. Therefore, this paper aims to explore the sports lifestyle and physical exercise behavior of rural adolescents in Yunnan border areas, which has practical guiding significance on promoting quality education in border areas.

\section{OBJECTS AND METHODS OF STUdy}

\section{A. Objects of Study}

Questionnaire testing is conducted on 552 students from 26 towns of Dehong Prefecture, Dai Autonomous Prefecture of Xishuangbanna, Zhuang and Miao Autonomous Prefecture of Wenshan, Honghe Prefecture and Baoshan City of Yunnan, including 258 boys and 294 girls.

\section{B. Methods of Study}

1) Literature Study: Using border areas, adolescents and sports lifestyle as key words to get access to research literature at home and abroad by CNKI, VIP database, Wanfang Data and some other search engines, and then sorting and comprehensively analyzing the existing research results and data, as well as interpreting the latest research trends of the study provide a strong theoretical basis for this study.

2) Interview: Communicating with some rural junior middle school students in Yunnan border areas on health status and physical activities, and interviewing leaders in charge of sports in local Education Bureau, and principals and head teachers of high schools in depth.

3) Questionnaire: Questionnaires on sports lifestyle are distributed to 552 rural junior middle school students in Yunnan border areas, 552 questionnaires are issued, 546 questionnaires are retrieved, and the recovery rate is $98.9 \%$. 504 copies of questionnaires are valid, so the effective rate is $91.3 \%$. 233 questionnaires of boys are valid, and 271 questionnaires of girls are valid. "Working Rules of 
Questionnaire" propose unified requirements for respondents, sample size, sampling methods, payment mode, data statistics and waste questionnaires removal method. Questionnaires are retrieved soon after being distributed, and the validity of the questionnaire is detected before sorting out the questionnaires.

\section{SURVEY RESULTS AND ANALYSIS}

\section{A. Attitude of Rural Adolescents in Yunnan Border Areas Towards Sports Activities}

Sports attitude refers to the overall performance of evaluation, experience and behavioral tendency on sports activities 3. Attitude on sports activities will directly affect the development of sports behavior, and especially for adolescents, their attitude will determine their participation in sports activities directly. From "Table I", it can be seen that the attitude of rural adolescents in border areas towards sports activities is relatively positive, and the positive degree of boys is higher than that of girls. Therefore, based on sports and health, we should actively promote girls' lifelong awareness in sports, and use a variety of teaching methods in physical education and extracurricular sports activities to enable girls to form a good sports attitude.

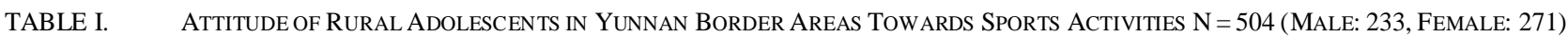

\begin{tabular}{|c|c|c|c|c|c|c|c|c|c|c|}
\hline Category & \multicolumn{2}{|c|}{ Extremely Like } & \multicolumn{2}{|c|}{ Like Very Much } & \multicolumn{2}{|c|}{ Like } & \multicolumn{2}{|c|}{ Not Like } & \multicolumn{2}{|c|}{ Hate } \\
\hline Number $\%$ & Number & $\%$ & Number & $\%$ & Number & $\%$ & Number & $\%$ & Number & $\%$ \\
\hline Male & 84 & 16.6 & 109 & 21.6 & 31 & 6.2 & 7 & 1.4 & 2 & 0.4 \\
\hline Female & 58 & 11.5 & 77 & 15.3 & 72 & 14.3 & 39 & 7.7 & 25 & 4.9 \\
\hline Total & 142 & 28.1 & 186 & 36.9 & 103 & 20.5 & 46 & 9.1 & 27 & 5.3 \\
\hline
\end{tabular}

\section{B. Participation of Rural Adolescents in Yunnan Border} Areas in Sports Activities

Behavior mode and participation degree of sports activities are based on the understanding attitude of sports activities 4. As can be seen from "Table II", the participation of rural adolescents in Yunnan border areas in sports activities is optimistic in general in school, and the comprehensive percentage of the two levels of regular participation and participation in sports activities is $81.6 \%$, which indicates that the participation degree of adolescents is high, but the differences between boys and girls are large. It can be known from the interview that the growth and development of boys and girls during the adolescence are different, resulting in the presence of a certain imbalance in participating in sports activities. Students selecting few participation in sports activities hold a positive attitude towards participating in sports activities, and have a certain understanding on the function of physical fitness, heart health, bodybuilding, and enhancing social adaptation of sports. The lack of sports facilities, heavy pressure of courses and lack of full-time teachers seriously affect adolescents' participation in sports activities. Some other rural children never participate in sports activities because they are not confident or afraid to be ridiculed by others.

It can be seen from "Table III" that the comprehensive percentage of the two levels of regular participation and participation in sports activities after school is $25.1 \%$, and the comprehensive percentage of the two levels of few participation and no participation in sports activities after school is $74.8 \%$, so the situation is not optimistic. The survey finds that most of the girls mainly do some housework and homework and usually watch TV in the remaining time. Furthermore, rural sports venues are limited, sports equipment are in lack, and many parents think that sports are just running and skipping, there is no need to engage in physical exercise and learning well is the primary thing, which make the extremely uneven trend of adolescents participating in sports activities after school. Participation in sports in school is good, while that after school is poor.

TABLE II. Participation of Rural Adolescents in Yunnan Border Areas in Sports Activities in School N=504 (Male: 233, Female: 271)

\begin{tabular}{|c|c|c|c|c|c|c|c|c|}
\hline \multirow{2}{*}{$\begin{array}{l}\text { Category } \\
\text { Number\\
% }\end{array}$} & \multicolumn{2}{|c|}{ Regular Participation } & \multicolumn{2}{|c|}{ Participation } & \multicolumn{2}{|c|}{ Less Participation } & \multicolumn{2}{|c|}{ No Participation } \\
\hline & Number & $\%$ & Number & $\%$ & Number & $\%$ & Number & $\%$ \\
\hline Male & 67 & 13.3 & 149 & 29.6 & 11 & 2.2 & 6 & 1.2 \\
\hline Female & 31 & 6.2 & 164 & 32.5 & 47 & 9.3 & 29 & 5.7 \\
\hline Total & 98 & 19.5 & 313 & 62.1 & 58 & 11.5 & 35 & 6.9 \\
\hline
\end{tabular}




\begin{tabular}{cllllllll}
\hline Category & \multicolumn{2}{l}{ Regular Participation } & \multicolumn{2}{l}{ Participation } & \multicolumn{2}{c}{ Less Participation } & \multicolumn{2}{c}{ No Participation } \\
\hline Numberl\% & Number & $\%$ & Number & $\%$ & Number & $\%$ & Number & $\%$ \\
Male & 33 & 6.5 & 41 & 8.1 & 105 & 20.8 & 54 & 10.7 \\
Female & 16 & 3.2 & 37 & 7.3 & 61 & 12.1 & 157 & 31.2 \\
Total & 49 & 9.7 & 78 & 15.4 & 166 & 32.9 & 211 & 41.9
\end{tabular}

\section{Participation Aims of Rural Adolescents in Yunnan Border Areas in Sports Activities}

According to "Table IV", most of rural adolescents in Yunnan border areas aim at keeping fit and adjusting body and mind while participating sports activities, the percentage of this item of boys reaches $72.7 \%$, and that of girls reaches $50.7 \%$, showing that most young people have a certain understanding on physical fitness function of sports. The aims of passing exam and enriching cultural life are followed, and boys and girls are basically the same on the orientation.
Most of the students have a clear understanding on sports' function of keeping fit and adjusting body and mind. But $57 \%$ of boys and $61.6 \%$ of girls select the item of passing exam, indicating examination-oriented education has a great impact on sports activities. From the interview, we know that the learning burden of teenagers in school is heavy, and PE exam accounts for 50 points in entrance examination, so a lot of students try to improve athletic performance through participating in sports activities to achieve the purpose of going to a school of a higher grade.

TABle iV. Participation Aims of Rural Adolescents in Yunnan Border Areas in Sports Activities N=504 (Male: 233, Female: 271)

\begin{tabular}{|c|c|c|c|c|c|c|c|c|}
\hline $\begin{array}{c}\text { Partici } \\
\text { pation } \\
\text { Aims }\end{array}$ & $\begin{array}{l}\text { Keeping Fit } \\
\text { and } \\
\text { Adjusting } \\
\text { Body and } \\
\text { Mind }\end{array}$ & $\begin{array}{c}\text { Passing } \\
\text { Exam }\end{array}$ & $\begin{array}{c}\text { Enriching } \\
\text { Cultural } \\
\text { Life }\end{array}$ & $\begin{array}{c}\text { Bodybuildin } \\
\text { g and } \\
\text { Losing } \\
\text { Weight }\end{array}$ & $\begin{array}{c}\text { Cultivati } \\
\text { ng } \\
\text { Personali } \\
\text { ty }\end{array}$ & $\begin{array}{c}\text { Social } \\
\text { Interaction }\end{array}$ & $\begin{array}{l}\text { Mastering } \\
\text { Skills }\end{array}$ & $\begin{array}{c}\text { Other } \\
\text { s }\end{array}$ \\
\hline $\begin{array}{l}\text { Male } \\
(\%)\end{array}$ & 72.7 & 57 & 45.3 & 8.9 & 24 & 23.3 & 37.1 & 3.9 \\
\hline $\begin{array}{c}\text { Female } \\
(\%)\end{array}$ & 50.7 & 61.6 & 49 & 44.2 & 19 & 18.7 & 23.5 & 3.4 \\
\hline
\end{tabular}

\section{Sports Items That Rural Adolescents in Yunnan Border Areas Participate in}

usually play the games like rubber band skipping and

According to "Table V", sports items that rural adolescents in Yunnan border areas participate are single, mostly examination programs and traditional items. Male and female students have a great difference in selecting. Boys select sports requiring strong force and large activity amount, such as basketball, table tennis, running and other projects. Girls select sports that are less adversarial and require less activity, such as badminton, running, volleyball and other projects. And in their spare time, boys and girls mainly play game. The sports items girls participate in are extremely single. In conversations with students, we find that physical education in middle school of rural areas mainly focuses on the items of senior high school entrance examination. In the interview with PE teachers and leaders of Department of Education, we find that grounds, equipment, teachers of many schools are in serious lack. One teacher has nearly 30 physical education classes in a week, each class has about 60 people, and many PE teachers also play several roles, so they simply cannot teach students something special. After school, many rural border areas simply have no sports venues, and parents usually require students to help them to do farm work or housework after school. Most children often play games in their spare time, boys usually play some games like catching the thief and throwing stones, while girls 
TABLE V. SPORTS Items That RuRAL AdOLESCENTS IN YunNAN BORDER AREAS PARTICIPATE IN IN SCHOOL AND AFTER SCHOOL N = 504 (MALE: 233, FEMALE: 271)

\begin{tabular}{|c|c|c|c|c|c|c|c|c|c|c|c|}
\hline \multicolumn{6}{|c|}{ In School } & \multicolumn{6}{|c|}{ After School } \\
\hline Boys & $\%$ & $\begin{array}{l}\text { Ran } \\
\text { king }\end{array}$ & Girls & $\%$ & $\begin{array}{l}\text { Rankin } \\
\quad \mathrm{g}\end{array}$ & Boys & $\%$ & $\begin{array}{l}\text { Ran } \\
\text { king }\end{array}$ & Girls & $\%$ & $\begin{array}{l}\text { Ran } \\
\text { king }\end{array}$ \\
\hline Basketball & 59.3 & 1 & Badminton & 47.1 & 1 & Game & 84.8 & 1 & Game & 89.4 & 1 \\
\hline $\begin{array}{c}\text { Table } \\
\text { Tennis }\end{array}$ & 32.2 & 2 & Running & 38.4 & 2 & Running & 83.2 & 2 & Running & 74.7 & 2 \\
\hline Running & 31.8 & 3 & Volleyball & 35.7 & 3 & Basketball & 16.6 & 3 & Badminton & 11.3 & 3 \\
\hline Football & 30.2 & 4 & Game & 27.9 & 4 & Football & 6.8 & 4 & Football & 0 & \\
\hline Badminton & 26.4 & 5 & Basketball & 24.1 & 5 & Martial Arts & 0.3 & 5 & Martial Arts & 0 & \\
\hline Volleyball & 12.8 & 6 & $\begin{array}{l}\text { Bodybuildin } \\
\text { g Exercise }\end{array}$ & 16.2 & 6 & $\begin{array}{l}\text { Parallel \& } \\
\text { Single Bars }\end{array}$ & 0 & & $\begin{array}{l}\text { Parallel \& } \\
\text { Single Bars }\end{array}$ & 0 & \\
\hline $\begin{array}{c}\text { Martial } \\
\text { Arts }\end{array}$ & 9.7 & 7 & $\begin{array}{l}\text { Table } \\
\text { Tennis }\end{array}$ & 13.6 & 7 & $\begin{array}{l}\text { Bodybuildin } \\
\text { g Exercise }\end{array}$ & 0 & & $\begin{array}{l}\text { Bodybuildin } \\
\text { g Exercise }\end{array}$ & 0 & \\
\hline Game & 8.5 & 9 & $\begin{array}{l}\text { Sports } \\
\text { Dancing }\end{array}$ & 6.5 & 9 & Volleyball & 0 & & Volleyball & 0 & \\
\hline $\begin{array}{l}\text { Parallel \& } \\
\text { Single Bars }\end{array}$ & 7.6 & 10 & Martial Arts & 3.1 & 10 & $\begin{array}{l}\text { Extreme } \\
\text { Sports }\end{array}$ & 0 & & $\begin{array}{l}\text { Extreme } \\
\text { Sports }\end{array}$ & 0 & \\
\hline $\begin{array}{l}\text { Bodybuildi } \\
\text { ng Exercise }\end{array}$ & 4.8 & 11 & $\begin{array}{l}\text { Parallel \& } \\
\text { Single Bars }\end{array}$ & 2.4 & 11 & $\begin{array}{l}\text { Sports } \\
\text { Dancing }\end{array}$ & 0 & & $\begin{array}{l}\text { Sports } \\
\text { Dancing }\end{array}$ & 0 & \\
\hline $\begin{array}{c}\text { Sports } \\
\text { Dancing }\end{array}$ & 2.7 & 12 & Football & 1.3 & 12 & Badminton & 0 & & Basketball & 0 & \\
\hline $\begin{array}{l}\text { Extreme } \\
\text { Sports }\end{array}$ & 0 & 13 & $\begin{array}{l}\text { Extreme } \\
\text { Sports }\end{array}$ & 0 & 13 & Table Tennis & 0 & & $\begin{array}{l}\text { Table } \\
\text { Tennis }\end{array}$ & 0 & \\
\hline
\end{tabular}

\section{E. The Form of Physical Exercise of Rural Adolescents in} Yunnan Border Areas

As can be seen from "Table VI", the form of physical exercise selected most by rural adolescents in Yunnan border areas is spontaneous small group, accounting for $52.7 \%$, indicating that they tend to participate in sports together, and most of them treat sports activity as a communication means and an important aspect to establish human relationship in daily life. School organizing sports accounts for $35.2 \%$, mainly during physical education, large recess, and schools basically organize no after-school sports. In the interview, we find that many rural schools in border areas do not organize different grades or classes to compete, competition only appears in winter sports meeting of school, and the school and the students themselves have not developed goaldirected and planned exercise programs. To a certain extent, these restrict the sports lifestyle cultivation of rural adolescents in border areas.

TABle VI. The Form of Physic al Exercise of Rural Adolescents IN Yunnan Border Areas N = 504 (Male: 233, Female: 271)

\begin{tabular}{|c|c|c|c|c|c|c|}
\hline \multirow{2}{*}{$\begin{array}{c}\text { Category } \\
\text { Number } \backslash \%\end{array}$} & \multicolumn{2}{|c|}{ Spontaneous Small Group } & \multicolumn{2}{|c|}{ School Organizing Sports } & \multicolumn{2}{|c|}{ Exercising Alone } \\
\hline & Number & $\%$ & Number & $\%$ & Number & $\%$ \\
\hline Boys & 104 & 20.6 & 86 & 17.1 & 43 & 8.5 \\
\hline Girls & 162 & 32.1 & 91 & 18.1 & 18 & 3.6 \\
\hline Ranking & 1 & & 2 & & 3 & \\
\hline
\end{tabular}

\section{F. Participation Frequency and Time in Sports Activities of} Rural Adolescents in Border Areas

Survey shows that rural adolescents in Yunnan border areas who participate in sports activities once or twice a week account for $26.4 \%$, and the adolescents who are not sure account for $48.2 \%$. $44.9 \%$ of students participate in sports activities for 30-60 minutes or less, but according to "Work Regulations of School Sports", primary and secondary school students must take extracurricular sports activities for more than three times every week; there is a requirement specifying an hour of sports activities every day, indicating that the participation time in sports activities of rural adolescents in Yunnan border areas is obviously insufficient, and the reasons for this situation may be multifaceted. From the interview, we know that many schools in border areas believe that sports is not important subject, it is not necessary to spend too much time, and a lot of parents think that it does not matter whether their children are good at sports as long as they have good academic achievements. And there is a widespread phenomenon that the time of physical exercise is occupied by academic learning. 
TABLE VII. PARTICIPATION FREQUENCY AND TIME IN SPORTS ACTIVITIES OF RuRAL AdOLESCENTS IN YunNAN Border AREAS N = 504 (MALE: 233, FEMALE: 271)

\begin{tabular}{clllllll}
\hline $\begin{array}{c}\text { Weekly Participation } \\
\text { Frequency }\end{array}$ & Boys \% & Girls \% & Total \% & Duration & Boys \% & Girls \% & Total \% \\
\hline Over 5 Times & 8.9 & 2.0 & 5.3 & Over 120 Minutes & 15.9 & 1.4 & 8.2 \\
3-4 Times & 12.0 & 10.2 & 11.1 & 90-120 Minutes & 14.7 & 10.5 & 12.5 \\
1-2 Times & 24.4 & 28.2 & 26.4 & 60-90 Minutes & 15.5 & 8.5 & 11.8 \\
Not Sure & 49.2 & 47.3 & 48.2 & 30-60 Minutes & 23.6 & 27.2 & 25.5 \\
No Participation & 5.4 & 12.2 & 9.1 & Below 30 Minutes & 13.6 & 24.5 & 19.4 \\
& & & & Not Sure & 16.7 & 27.9 & 22.6 \\
\hline
\end{tabular}

\section{G. Sports Consumption Content and Consumption Level of \\ Rural Adolescents in Border Areas}

Sports consumption refers to the economic investment for sports lifestyle. Sports consumption level of adolescents is directly related to their loving degree for sports as well as family's economic situation. 5 It can be seen from "Table VIII" that $39.7 \%$ of junior school students spend less than 100 yuan per year on sports consumption, and the sports consumption between 100-200 yuan accounts for 53\%. The above data show the consumption level of rural adolescents in Yunnan border areas is relatively lower, in addition, there are also differences between boys and girls in sports consumption, and overall, the sports consumption of boys is slightly higher than that of girls. In consumption content, "Table IX" shows that adolescents mainly purchase sports equipment, apparel, sports newspapers and audio-visual products. The consumption level is relatively single and low. From the interview, we know that the above situation is mainly because the consumption awareness of junior high school students in rural areas is low, and family economic difficulties restrict their consumption. For some adolescents, purchasing sports clothing and equipment is for taking PE class and participating in physical examinations. Furthermore, sports awareness of some students and parents is weak, not to mention sports consumption.

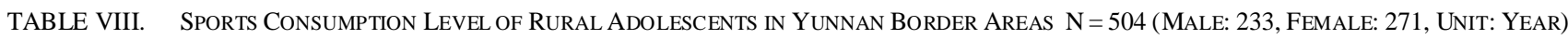

\begin{tabular}{|c|c|c|c|c|c|c|}
\hline No. & $\begin{array}{c}\text { Annual Average Sports } \\
\text { Consumption }\end{array}$ & Male & $\%$ & Female & $\%$ & Total \% \\
\hline 1 & Below 50 yuan & 23 & 4.6 & 57 & 11.3 & 15.9 \\
\hline 2 & $51-100$ yuan & 46 & 9.1 & 74 & 14.7 & 23.8 \\
\hline 3 & $100-150$ yuan & 92 & 18.3 & 64 & 12.7 & 31.0 \\
\hline 4 & 151---200yuan & 55 & 10.9 & 56 & 11.1 & 22.0 \\
\hline 5 & 201---250yuan & 11 & 2.2 & 13 & 2.6 & 4.8 \\
\hline 6 & 251---300yuan & 4 & 0.7 & 7 & 1.4 & 2.1 \\
\hline 7 & Over 300 yuan & 2 & 0.4 & 0 & 0 & 0.4 \\
\hline
\end{tabular}

TABLE IX. SPORTS CONSUMPtion CONTENT OF Rural AdOLESCENTS IN YunNan Border AREAS N = 504 (MALE: 233, Female: 271)

\begin{tabular}{|c|c|c|c|c|c|c|}
\hline No. & Consumption Content & Male & $\%$ & Fe male & $\%$ & Total\% \\
\hline 1 & $\begin{array}{l}\text { Purchasing sports equipment and } \\
\text { clothing }\end{array}$ & 189 & 37.5 & 217 & 43.1 & 80.6 \\
\hline 2 & $\begin{array}{l}\text { Purchasing sports newspapers and } \\
\text { audio-visual products }\end{array}$ & 28 & 5.6 & 47 & 9.3 & 14.9 \\
\hline 3 & $\begin{array}{l}\text { Participating in club exercise and } \\
\text { other participation consumption }\end{array}$ & 2 & 0.4 & 0 & 0 & 0.4 \\
\hline 4 & $\begin{array}{l}\text { Watching sporting events and other } \\
\text { view consumption }\end{array}$ & 2 & 0.4 & 3 & 0.5 & 0.9 \\
\hline 5 & Participating in sports training & 0 & 0 & 0 & 0 & 0 \\
\hline 6 & Sports lottery & 3 & 0.5 & 0 & 0 & 0.5 \\
\hline 7 & Others & 9 & 1.8 & 4 & 0.8 & 2.6 \\
\hline
\end{tabular}

\section{H. Factors Restricting Participation in Sports Activities of} Rural Adolescents in Border Areas

It can be seen from "Table X" that the primary factor restricting participation in sports activities of rural adolescents in border areas is the lack of venues and equipment, followed by weak economic support. This shows that the venues and equipment of each school cannot fully meet the need of students to participate in sports activities, so that school authorities should pay attention to this situation, strengthen and improve the environment of physical exercise, and provide convenience for students to conduct physical exercise. In addition, important factors restricting students' participation in sports activities are lack of time, no guidance, and no specialist to organize. Aiming at these situations, schools should reduce the learning burden of students, strengthen the organization and leadership of physical activities, conduct interest guidance on students and encourage them to form lifelong sports consciousness. 


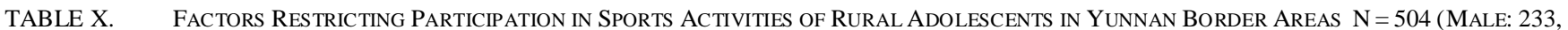
FEMALE: 271)

\begin{tabular}{|c|c|c|c|c|c|c|c|c|c|}
\hline $\begin{array}{l}\text { Restrict-- } \\
\text { ing } \\
\text { Factors }\end{array}$ & $\begin{array}{c}\text { Lack of } \\
\text { Venues and } \\
\text { Equipment }\end{array}$ & $\begin{array}{c}\text { No } \\
\text { Time }\end{array}$ & $\begin{array}{c}\text { No } \\
\text { Guidance } \\
\text { and } \\
\text { Organization }\end{array}$ & $\begin{array}{c}\text { No } \\
\text { Interest }\end{array}$ & $\begin{array}{l}\text { Poor } \\
\text { Skill }\end{array}$ & $\begin{array}{c}\text { No } \\
\text { Support } \\
\text { from } \\
\text { Parents }\end{array}$ & $\begin{array}{c}\text { Poor } \\
\text { Economic } \\
\text { Condition }\end{array}$ & $\begin{array}{c}\text { Heavy } \\
\text { Learning } \\
\text { Burden }\end{array}$ & Others \\
\hline $\begin{array}{c}\text { Male } \\
(\%)\end{array}$ & 47.1 & 11.3 & 25.1 & 3.6 & 9.7 & 12.9 & 33.4 & 10.2 & 2.7 \\
\hline $\begin{array}{c}\text { Female } \\
(\%)\end{array}$ & 41.2 & 35.0 & 28.2 & 25.6 & 10.5 & 13.7 & 41.3 & 14.5 & 1.4 \\
\hline
\end{tabular}

\section{CONCLUSION AND RECOMMENDATION}

\section{A. Conclusion}

- Students' participation in physical exercise in schools is much more, but their purposes are usually not clear, sports items they participate in are relatively simple, examination-oriented education of sports is obvious, exercise time is short, and students who persist in long-term physical exercise are few.

- Students' participation in sports after school is less, sports items are mainly games, and the rest time is mostly occupied by homework and housework.

- Sports consumption level of rural adolescents in border areas is low, and their sports consumption awareness needs to be further improved.

- There are a variety of factors restricting junior high school students to participate in sports activities, including biased sports concept, inadequate equipment, weak economic support, no guidance and organization, and no time.

\section{B. Recommendation}

- Strengthening education, enriching adolescents' sports activities, and developing good and scientific health habits. Schools and physical education teachers should change the thinking of examination-oriented education, and try to achieve diversification in sports curriculum, such as optional course clubs, individual clubs in schools and class sports competitions, in order to enrich students' sports life. PE teachers should promptly popularize some new sports items and advanced sports and health knowledge to students, while cultivating students' sports emotions, beliefs and behavior through a variety of flexible teaching methods, striving to make young people establish lifelong sports ideology. Establish appropriate sports interest groups or clubs after school, to enrich students' extracurricular sports activities. Deliver sports knowledge to parents via students, to get as much support and understanding from parents as possible.

- Good sports facilities and sports atmosphere can stimulate the desire of people to participate in sports. Improve the construction of sports facilities in rural schools and villages, optimize sports exercising environment and identify national sports resources, to meet the needs of students 'daily physical exercise, to improve students' sports consumption level, and to provide a workout platform for students to develop a lifelong habit of physical exercise.

- Through carrying out sports and cultural activities in the countryside, strengthen physical culture publicity and provide sports knowledge, technique, mental health counseling and other services for rural areas, in order to improve the rural population's awareness of sport and health.

Physical activity is an important part of adolescents' life content. Healthy sports lifestyle is an important aspect to enrich the culture and entertainment of adolescents, a healthy and civilized life style, and one of indispensable activities to develop body, mind and character6. Therefore, I hope the above suggestions will provide a reference for rural schools in border areas to cultivate students' "healthy" sports lifestyle, so as to promote the overall development of students' virtue, intelligence, physical conditions and mind status and the practical development of quality education in border areas.

\section{REFERENCES}

[1] Miao Dapei. On Sports Lifestyle[M]. Beijing: Beijing Sports University Press, 2004: 90.

[2] Li Wenchuan, Xiao Huanyu. Concept Defining and Category Structure of Sports Lifestyle[J]. Journal of Shanghai Institute of Physical Education, 2010 (3): 33-37.

[3] Jiang Guifeng et al. Analysis on Sports Attitude and Sports Behavior in the Spare Time of Junior School Students in Colleges of Hunan Province[J]. Journal of Shanghai Institute of Physical Education, 2005 (10): 106-109.

[4] Yang Xiulan. On the Sports Life of Junior School Students[J]. Journal of Xi'an Institute of Physical Education, 1995 (3): 54-56.

[5] Gong Hua. Status Survey and Countermeasures Study of the Sports Lifestyle of Junior School Students in Colleges of Dalian [J]. Journal of Liaoning Normal University, 2006 (8): 42-43.

[6] Lin Zuming. Analysis on Sports Life and Health of Junior School Students in Colleges[J]. Journal of PLA Institute of Physical Education, 2004 (3): 33-36 